\title{
日本漢方の特徴
}

\author{
寺澤 捷年 \\ 東亜医学協会理事長，東京，テ101-0065 千代田区西神田2-7-4 島崎ビル
}

\section{The Specific Characteristics of Japanese Kampo Medicine}

\author{
Katsutoshi TERASAWA
}

President, The Association of East-Asian Medicine, 2-7-4 Nishikanda, Chiyoda-ku, Tokyo 101-0065, Japan

\begin{abstract}
Over the past few years, a significant problem has been raised in the field of traditional East-Asian medicines, i.e. the ISO/TC 249 action, which is intended to unify traditional East-Asian medicines with traditional Chinese medicine (TCM).

There is historical evidence that the Korea and Japan imported ancient Chinese medicine in the past, however, either country has greatly its reformed Chinese medicine resulting vast differences from the current TCM. This paper intends to reveal the differences between Kampo and TCM from the viewpoint of disease recognition methods. Kampo recognizes a disease via structuralism, whereas TCM depends on element reduction theory, i.e. The Five Elements and so on. Kampo is based the theory whereby a sho (sign / symptom / indication for) correlates with a formulation. The character of each formulation can be acquired through tactile knowledge with clinical experience mainly based on abdominal findings.

To expand, a Sho represents the name of its most proper formulation, such as with kakkonto-sho. In other words, a disease entity is expressed in the name of its treatment. This means that Kampo does not lend itself to Chinese element reduction theory, but rather, is used restrictively as a matter of explanation for a selected formulation. Thus there are fundamental philosophical difference between the current TCM and Kampo, so that we cannot agree with the Chinese government's ISO proposal by which both modalities would be brought under the same Chinese heading.

Key words : Kampo, structuralism, tactile knowledge, explicit knowledge, element reduction theory

\section{要旨}

ここ数年, 東アジア伝統医学の領域に重要な問題が起こっている。国際標準化（ISO/TC249）の動きである。こ れは東アジアの伝統医学を中医学に統一することを意図している。確かに韓国と日本の伝統医学は古代の中国医学 を源としているが, それを受容した後に各国で大きな变革を遂げており，現在の中医学とは大きく異なっている。 本論文は日本漢方と中医学の相違を疾病の認識法の観点から明らかにした。漢方医学は疾病を構造主義的に認識す るが, 他方, 中医学は五行論などの要素還元論に依っている。漢方医学は方証相対論を基本としており, 各々の方 剤の性質は腹診を重視する臨床経験による暗黙知として獲得される。その結果, 証はこれに対応する最適の方剂名 として, たとえば葛根湯証として認識される。これが日本漢方における病名表記である。言い換えると, 漢方医学 では要素還元論は採用しないのであって, 選択された方剤の説明の材料として限定的に用いられる。つまり，両者 は哲学的方法論において根本的に異なっており, これを一つの国家の名称を冠した国際標準にすることには同意で きないのである。
\end{abstract}

キーワード : 漢方, 構造主義, 暗黙知, 形式知, 要素還元論

\section{緒言}

近年，中国政府は国策として中医学を国際標準規 格にすべく ISO/TC249を立ち上げた。この国際問 題に対し，日本東洋医学会はJLOM（日本東洋医学 サミット会議）を通じ，また経済産業省とも連携し て対応しているところである。またこれとは別に
WHOによる国際疾病分類（ICD）の改定に際し， 伝統医学の疾病分類を加えるための努力もなされて いる。

そこで問題となるのは, 日本漢方とは何か。中医 学との本質的な相違は何か。日本漢方における疾病 分類は如何にあるべきかである。 
本稿はこれらの諸点について, 前報の「医界之鉄

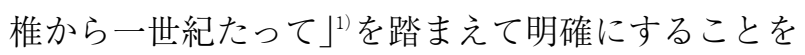
意図したものである。

\section{1. 吉益東洞の医論}

前報の「医界之鉄椎から一世紀たって」的に詳述し たように，日本漢方と一括りにされる知の体系も， その歴史の必然的な結果から多様なものとなってい る。しかし，これを特徵づける大きな基本骨格は吉 益東洞（1702-1773）の医論である

東洞は伝統的な中国医学の理論（陰陽・五行・臟 腑・経絡）を全て否定して, 実存的経験論あるいは 構造主義的認識法 ${ }^{3}$ とも呼べる独自の医論を提唱し た。その基本骨格を列記すると次のようなものであ る。

1 ）思弁・憶測を持たずに，実体に則した観察を根 拠とした，本当に患者を治すことの出来る医者「疾 医」でなければならない。

2 ) 理想とすべきは, 古代の医者・扁鵲である。学 ぶべきは上古である。そこには思弁・憶測・修飾の 無い「ありのままの世界」が広がっている。

3 ) 病気を種々に分類し, 病名を付け, 対処法を論 じる既存の中国医学は思弁・臆断に凝り固まってい る。全ての病気は一つの毒によって起こるものであ り,体内で形を変えて出現しているに過ぎない。従っ てこの毒を薬という毒（毒薬）で排除すればよい。 これを「万病一毒」と言う。

4 ）漢方方剂は古代の原形に近いものが好ましい。 なぜならば上古の方剤は疾医の工夫になるもので, 実際に用いてよく効く。従って最も古く成立した張 仲景方（傷寒論・金圚要略）に基本的に準拠すると よい。ただし，傷寒論・金貴要略には後人が思弁・ 臆断で書き加えた部分が多々混在するので, 古代の 原形を選び出さなければならない。最も重要なこと は，方剤にはそれが適当する毒の容・「証」がある から，この証に合わせて方剤を投与することである。 これを「方証相対」と言う。

5 ）毒薬を用いて毒を攻めるのであるから, その治 癒過程で激しい反応が見られる。これを瞑眩と言う。 古人も「薬を与えて瞑眩が見られないようでは，そ の病気は治らない」と言っている。この瞑眩を恐れ ていては疾医の道は獲得できない。

6 ）毒薬を与えて患者が死亡することもある。しか し, それは薬によるものではない。そもそも, 生死
は天が司る所であって, 人間の思惟の及ばぬことで ある。従って医者は「生死は知ら奴心に決めて, 生死の事は天に任せ，ひたすら疾病の治療に最善を 尽くせばよい。これを,「人事を尽くして天命を待 つ」と言うのである。

7 ）漢方方剂は，それがたとえ上古の方剤であれ， 後世のものであれ, 臨床の場で, 親しくこれを実際 に繰り返し試し，その病症の容（証）と効果を検討 しなければならない。生薬についても同じことであ る。そして効果が確認できたものを用いる。これを 「親試実験」と言う。「親試実験」によって納得が 行くものであれば，後世の方剤を用いて何ら差し支 えない。

8）一切の思弁・臆断を排除して，毒の容を見抜か なければ，適当する方剤は選択出来ない。そのため には毒の実体を手にすることであり，これには腹部 の診察が最も重要である。腹部に現れている圧痛・ 凝り・筋肉の拘縮・腹部の動悸等の有無を丹念に診 察することである。次いで重要なのは体表部の所見 で, 汗が出ているか否か, 上半身に熱感があって下 半身が冷えていないか, 発赤や腫脹は無いか, 浮腫 は無いか, 大便と小便の回数や性状。これらを詳細 に観察し, 或いは聴取するのである。この方剤の適 当する容（証）は臨床の実際に於いて「自得」する ものであって, 子供にも伝えられない。勿論, 文字 にも出来ない。

この思想の根底には野中郁次郎の言う「暗黙知」 と「形式知」の問題が存在する ${ }^{4)}$ 。つまり, 患者が 呈している病症の容を見定めると言う臨床の知は 「暗黙知」であって, 本質的に「形式知」として言 語表現できないのである。

上述の 8 ）項の末尾にある「この方剂の適当する 容（証）は臨床の実際に於いて自得するものであっ て, 子供にも伝えられない。勿論, 文字にも出来な い」という文言はこのことを言っている。

もちろん，その言語化できない「暗黙知」を陰陽 五行論などの言語を用いて如何様にも論理を展開で きる。しかし「言語」は本質を全て表現できないし， 五行などの要素に還元する方法論は総体の真実には 迫れない。従って, ある「暗黙知」から出発した要 素還元的な論理展開の抱える最大の問題は, その論 理を逆に上流へと遡っても, 出発点であった「暗黙 知」には到達できないのである。 
表 1 保険薬価収載の漢方エキス製剤の出典分類

a. 傷寒論・金實要略 を出典とするもの。古方派の常用方㓮である。 茵蔯蒿湯 茵蔯五苓散 温経湯 越婢加术湯 黄偖建中湯 黄芩湯 黄連湯 葛根湯 甘草湯 甘麦大雵湯 桔梗湯 芦帰膠艾湯 桂枝加黄耆湯 桂枝加葛根湯 桂枝加厚朴杏仁湯 桂枝湯 桂枝加芳薬湯 桂枝加芳薬大黄湯 桂枝加竜骨牡蚛湯 桂枝芳薬知母湯 桂枝人参湯 桂枝获苓丸 桂麻各半湯 呉葉莫湯 五苓散 柴胡加竜骨牡蚛湯 柴胡桂枝湯 柴胡桂枝乾姜湯 三黄鴧 心湯 酸雵仁湯 三物黄芩湯 四逆散 梔子柏皮湯 多甘草湯 芳薬甘草湯 小建中湯 小柴胡湯 小青竜湯 小半夏加获苓湯 真武湯 大黄甘草湯 大黄牡丹皮湯 大建中湯 大柴胡湯 大承気湯 調胃承気湯 猪苓湯 桃核承気湯 当帰建中湯 当帰四逆加㺯茱萶生姜湯 当帰药薬散 人参湯 排澧散及湯 麦門冬湯 八味地黄丸 半夏厚朴湯 半夏澶心湯 白虎加人参湯 获苓飲 防已黄耆湯 麻黄湯 麻黄附子細辛湯 麻杏甘石湯 麻杏害甘湯 麻子仁丸 木防已湯 苓甘姜味辛夏仁湯 荅姜术甘湯 苓桂术甘湯（69 万方）

b. 外台秘要方・千金方（6-8 世紀）を出典とするもの。各派が常用するもの。 黄連解毒湯 神秘湯 晹㿑湯 当帰湯 (4 万)

c. 和剤局方・万病回春・済生方・女科撮要 など、後世方派・折哀派が常用す るもの。

安中散 胃苓湯 温清飲 加味帰脾湯 加味道遥散 帰脾湯 芦帰調血飲 啓脾湯 香蘇散 五虎湯 五積散 牛車腎気丸 五淋散 滋陰降火湯 滋陰至宝湯 四君子湯 四物湯 十全大補湯 潤腸湯 消風散 升麻葛根湯 辛夷清肺湯 参蘇飲 清上防風湯 清暑益気湯 清心蓮子飲 清肺湯 川芦茶調散 疎経活血湯 大防風湯 竹茹温胆湯 釣藤散 通導散 当帰飲子 二尤湯 二陳湯 女神散 人参養栄湯 半夏白术天麻湯 附子理中湯 平胃散 防風通聖散 補中益気湯 㥕莰仁湯 抑肝散 六君子湯 竜胆湯肝湯 六味丸 (48 方)

d. 本朝経験。我が国で創方されたもので、各派が共に用いるもの。 乙字湯 葛根加术附湯 葛根湯加川芦辛夷 九味檳榔湯 荊芥連趋湯 桂枝加术附湯 桂枝加苓术附湯 桂枝茯苓丸加薏茊仁 柴陥湯 柴胡清肝湯 柴朴湯 柴荅湯 七物降下湯 十味敗毒湯 小柴胡湯加桔梗石高 治頭㝓一方 治打撲一方 猪苓湯合四物湯 获荅飲合半夏厚朴湯 抑肝散加陳皮半夏 立効散（2 1 方）

それでは「暗黙知」そのものを全体的に把握する 方法論とは何か。東洞は実体のある身体所見である 腹部症候あるいは体表部症候をその把握法として介 在させたのである。ここでは何故その腹部症候が出 現するのかは問題としない。システム制御論的に言 えば，構造主義的 ${ }^{3}$ に捉えられるブラックボックス の容に適当する方剤（ブラックボックス）を対応さ せて問題の解決を図るのである。「日本漢方」で腹 診をとりわけ重視するのはこのブラックボックスの 容の認識において腹部症候が精度の高い情報を提供 するからである。

吉益東洞のもう一つの偉大な業績は「方剤の独 立」を明確にしたことである。その具体的成果は『類
聚方』である。それまで方用は病名として区分され る特定の病症に用いるものとして認識されていたが， 東洞は病名区分を無意味なものとし「万病は一毒」 としたので, 方剤は病名区分から解放され, その方 郕が適当する病態（毒の容）に応じて活用すべきも のと位置付けられたのである。具体例をあげれば, 日本漢方では柴胡桂枝湯を常習頭痛, 慢性肝炎, 慢 性膵炎, 脊柱管狭窄症, 過敏性腸症候群, 感冒の亜 急性期など実に様々な病名に自由に用いているが, その方法論を開拓したのは吉益東洞である。その際 に重要なのは柴胡桂枝湯の容が備わっていることで あって，その一端を記述するならば，上衝傾向，自 然発汗傾向, 胸脇苦満, 腹直筋の緊張, 神経過敏な 
どが同時的に表出されていることである。

\section{2 ．東洞医論とその後の展開}

日本漢方は東洞医論を基調とするが，純粋にそれ のみを金科玉条としてしまうと，初学者は羅針盤の ない航海を強いられることになる。そこで，東洞の 次世代以後は東洞が全否定した陰陽論, 気血水論, 五臓論などを適宜採用する経過を辿った。その際, 最も影響を与えたのは，当時，医学の主流であった 曲直瀬道三（1507-93）の医論である。曲直瀬道三 は金元医学に独自の工夫を加えたが，その内容をそ の著書『啓迪集』(1574年自序 $)^{5}$ に見ると，中国医 学の観念論的でしかも複雑細緻な理論を極めて簡素 化し，方剤の適応する容を求める方向で記述が為さ れている。つまり，方証相対の原形を思わせるもの であって，この傾向はその「中風門」「傷寒門」に おいて特に顕著である。

筆者がここで指摘したいことは，曲直瀬道三とそ れに連なる学統は，それを彼らが明確に意識してい たと否とに拘わらず，方剤選択の羅針盤として，補 助的に陰陽五行論などを用いていたのである。その 具体例は道三の養嗣子・曲直瀬玄朔（1549-1631） の治験録『医学天正記』(1627刊 $)^{6}$ の記述に見るこ とができる。そこには要素還元的な論理を積み上げ て方片の適応となる容に溯上する姿ではなく，直接 的に適応となる方剤に到達している様が示されてい る。

吉益東洞の方法論に準拠する学統を古方派と称し, 道三流の学統を後世方派と言う。東洞の活躍した当 時（18世紀中葉）両派は劇しく対立していたが，医 療の実践と子弟の教育という観点に立てば，両派の 方法論を巧みに活用すれば良いことに気付くのは当 然で，幕府医学館を中心に両者を折贵する学派が誕 生した。この学統を折禹派と称する。折贵派の一人 に分類される浅田宗伯（1815-1894）は『勿誤薬室 方函口訣』7著しているが，方剤は「いろは順」に 列記されている。これは東洞が方剤を病名の束縛か ら解き放ち，「方剂の独立」を唱えた路線を継承し たものと考えて良い。

\section{3 . 日本漢方の内容}

上述した経緯を経て，日本漢方は後世派，古方派， 折患派が誕生したが，この流れは現在にも存在する。 大正～昭和初期 (大戦前) の学統は以下の 4 群に分 類される。
(1)和田啓十郎（1872-1916), 湯本求真（18761941），大塚敬節（1900-80）の古方再発掘の流 れ $\rightarrow$ 皇漢医学派（古方派に属する）

(2)奥田謙藏（1884-1961）, 和田正系，藤平健 （1914-1997），小倉重成らの流れ $\rightarrow$ 古方派

(3)森道伯, 矢数格から矢数道明（1905-2002）の 流れ $\rightarrow$ 後世方派

(4)新妻荘五郎，細野史郎（1899-1988）加坂口 弘（1921-2003）の流れ $\rightarrow$ 折東派・浅田流

しかし，江戸期との決定的な違いは，1930年代に 興った大同団結による各学派の交流と協力体制であ る。筆者は1931年～41年の期間を今日見る「日本漢 方」の摇籃期と考えている。そして，終戦後にこの 大同団結は日本東洋医学会（1950年）の創設と東亜 医学協会の再発足（1954年）として結実した。

このような相互交流によって育まれた現在の「日 本漢方」の特徵を列記すると次のようになる。

1 ）方証相対論（随証治療）を基本としている。

2 ) いずれの学派も腹診を重視している。

3 ）脈診の方法には各派で相違がある。古方派は三 部九候を採用せず，折褁派・後世方派は採用す る傾向を持つ。

4 ) 中医学に抢けるような要素還元的な論理の積み 上げによって証を確定するという弁証論治の手 法は採らず，あくまで構造主義的な実体に基づ く暗黙知の直接把握を優先し, その過程におけ る補助的手段，あるいは説明の手段として㓌陽 論，気血水論，五臟論を用いている。

5 ）従って, 日本漢方においては血痺症, 肝陽虚症 などという病名は用いず，葛根湯証，柴胡桂枝 湯証などが疾病分類の用語とされている。

6 ) 東洞医論は観念論を排除して, 実体のある症候 に手がかりを求めた。今日の日本漢方も西洋医 学的な画像診断, 病理診断などの病態認識も動 員して証の確定に組み入れる努力を遂行してい る。

7 ）実際の臨床において, 漢方方剂と西洋薬の適切 かつ安全な併用を場合に応じて行っている。

8 ）血液生化学検査などを適宜行い, 臨床効果の客 観的評価と副作用モニタリングを日常的に行っ ている。

以上のような共通点を持つとは言え, 各流派は 各々が得意とする常用方剂を持つのは当然である。 
表 2 仲景方以外の方剤の扱い（代表例）

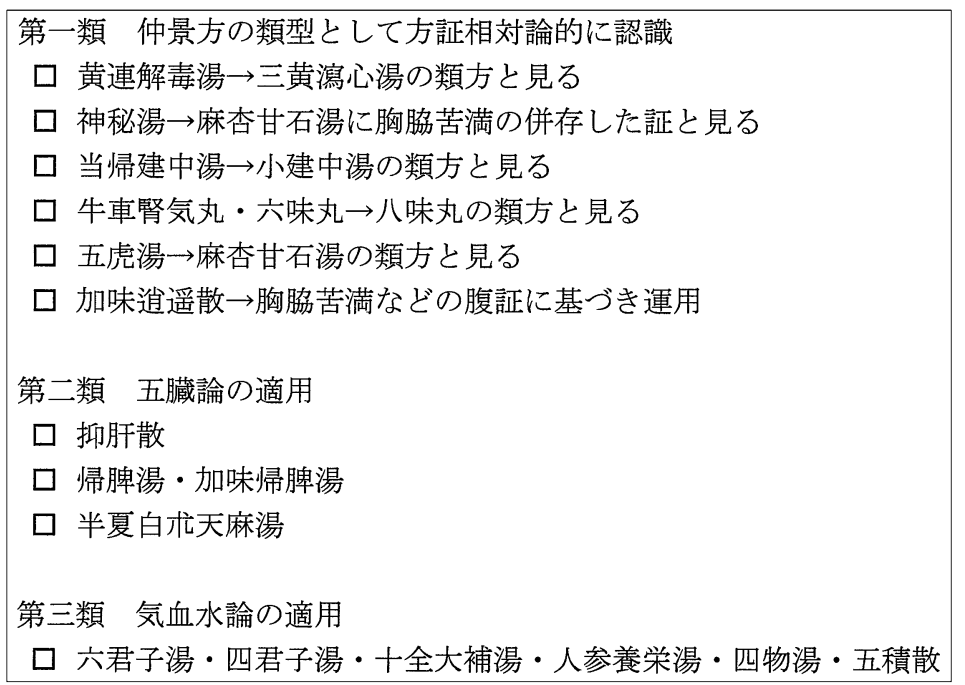

実は，我が国の厚生労働行政もこの点について十分 な配慮をして来たことが薬価収載の漢方エキス製剤 の出典から理解される (表 1 )。

また，表 1 における仲景方以外の方剂も，仲景方 の類方として認識し，方証相対的に用いられること が多い。また，適宜，五臓論や気血水論が採用され ている(表つ)。

\section{結語}

日本漢方の特徴について論じた。近代西洋医学の パラダイムと日本漢方のパラダイムの根本的な相違 は西洋医学が要素還元論を基盤にしているのに対し て，日本漢方は構造主義を基盤としている点にある と言える。構造主義の観点からすると, 雑然と表出 される生体の闘病反応も相互の関係性において整然 とした証として，一括して捉えることができるので ある。

これとほぼ同様のことが中医学と日本漢方につい ても言えるのである。すなわち五行論は 5 つの要素 に還元することであり，陰陽論は二元論への要素還 元，気血水論は三元論への要素還元論に他ならない。 近代科学の要素還元論が心身一如のダイナミックな 存在としての人間を全て説明することが不可能であ るのと全く同様に，中医学における要素還元論を以 てしても「ありのままの病症」を正しくは表現する
ことはできないのである。

構造主義的な証の把握は「暗黙知」であり, 本質 的には全てを「形式知」にはできない。東洞が「自 得」するものであるという通りである。しかし教育 の場で「証は暗黙知であるから自得せよ」とは言え ない。従って，凡その方向を示す羅針盤として陰陽， 虚実，気血水そして五臓論を便宜的に用いる事にな るのである。また日本漢方を担う人々に課せられた 使命は可能な限り暗黙知を形式知として，その「あ りのままの姿」の一端を丁寧に記述することである。

\section{参考文献}

1 ）寺澤捷年：『医界之鉄椎』から一世紀たって, 日東医 誌，63，89-97，2012

2 ) 寺澤捷年：吉益東洞の研究一日本漢方創造の思想，岩 波書店, 2012印刷中

3 ）池田清彦：構造主義科学論の冒険，毎日新聞社，1990

4 ) 野中郁次郎, 紺野登: 知識創造の方法論, 東洋経済新 報社, 2003

5 ) 大塚敬節 - 矢数道明編: 漢方医学書集成 2 , 曲直瀬道 三，啓迪集，名著出版，1979

6 ）大塚敬節 - 矢数道明編: 漢方医学書集成 6 , 曲直瀬玄 朔, 医学天正記, 名著出版, 1979

7 ) 大塚敬節 - 矢数道明編 : 漢方医学書集成 96 , 浅田宗伯, 勿誤薬室方函口訣，名著出版，1982 